\title{
Transição política e cotidiano penitenciário
}

Eda Maria GÓES'1

R E SU M 0: Este trabalho dedica-se ao estudo das décadas de 1980 e 1990 no Brasil, a partir da transição política, mas procurando abordar também seus desdobramentos que se materializaram, em grande parte, nos anos 1990. A abordagem baseia-se no estabelecimento de relações entre as mudanças políticas, em suas possibilidades e seus limites, e no cotidiano de instituições penitenciárias do Estado de São Paulo inicialmente, e posteriormente em uma região específica, o O este Paulista. Chegou-se assim à identificação das diferentes temporalidades próprias de cada uma delas, por vezes materializadas em fissuras no processo de democratização que envolvia o debate acerca dos direitos humanos, al ém da identificação das relações de poder comuns e específicas.

Pa Lavra S- ch ave: Penitenciárias paulistas; Regime militar; história do cotidiano.

Este trabalho dedica-se ao estudo das décadas de 1980 e 1990, a partir da transição política que caracterizou o fim do regime militar no Brasil, mas procurando abordar também seus desdobramentos que, de acordo com a hipótese de trabal ho adotada, se materializaram, em grande parte, nos anos 1990.

Diante detal desafio, a perspectiva adotada foi interdisciplinar, sob uma temática específica entendida como estratégica neste contexto político, que é a questão da atuação das chamadas instituições de controle social, particularmente o caso das penitenciárias do Estado de São Paulo. Desse modo, a participação num grupo de pesquisa composto por geógrafos, economistas e historiadores (GAsPERR - Grupo de Pesquisa eProdução do Espaço e Redefinições Regionais) que, além de explorar a bibliografia produzida por outros cientistas sociais adotou um recorte regional (O este do Estado de São Paulo), permitindo trazer para o campo da História suas contribuições e, a partir deste campo, produzir novos e relevantes conhecimentos sobre essa temática. 
A ênfase na temporalidade - se compreendida como âmbito das mudanças e permanências não como categorias excludentes, mas envolvendo movimentos contraditórios, avanços e retrocessos, além de conferir especificidade à abordagem histórica - favoreceu o necessário estabelecimento de relações entre as diferentes contribuições dos outros profissionais de áreas afins, ou seja, entre as diferentes dimensões das temáticas em questão.

0 estabelecimento de relações entreas mudanças políticas, em suas possibilidades e seus limites, com o cotidiano de instituições penitenciárias do Estado de São Paulo inicialmente, e posteriormente de uma região específica, o O este Paulista, permitiu a identificação das diferentes temporalidades próprias decada uma delas, por vezes materializadas em fissuras no processo de democratização que envolvia o debate acerca dos direitos humanos, além da identificação das relações de poder comunse específicas de cada uma.

A partir da inauguração de mais de dez dessas instituições durante os anos 1990 na região estudada, as relações entre o interior e o exterior das mural has das penitenciárias tem merecido atenção específica, levando-seem conta, entreoutrosaspectos, o papel desempenhado pela mídia, como principal reestruturadora da chamada esfera pública que, por conseqüência, torna-se uma das principais influências nas representações sociais produzidas sobre presos, criminosos, jovens infratores, agentes penitenciários, etc.

ANOS 1980: TRANSIÇÃO POLÍTICA E TENTATIVA DE HUM ANIZAÇÃO DOS PRESÍDIOS PAULISTAS

No Brasil difundiu-se a idéia de que os últimos anos do regime militar, iniciado em 1964, caracterizaram-se como uma transição democrática. A periodização empregada, que situa essa transição na década de 1980, é reveladora da estratégia das lideranças políticas de segmentos das elites para encobrir os embates que vinham caracterizando a cena política brasileira desde a década de 1970 .

Como qualificar o papel desempenhado pelas greves ocorridas na região do ABC (na Grande São Paulo) em 1978 e 79? E quanto aos mo- 
vimentos de bairro contra a carestia? E a ampla mobilização pela anistia dos presos políticos e exilados, articulada principalmente pela Comissão de Justiça e Paz da Arquidiocese de São Paulo, da I greja Católica, e pela OAB (Ordem dos Advogados do Brasil)?

A funcionalidade dessa conceituação reside, portanto, na definição de uma única saída possível para a ditadura: a democracia liberal, com o retorno às liberdades democráticas, à legitimidade e ao interesse pelas questões sociais, porém sempre sob o controle das lideranças políticas tradicionais. A ampla movimentação iniciada na década anterior foi desqualificada pelo discurso político hegemônico e relegada ao esquecimento, restando mais uma vez uma história oficial linear e harmônica.

No que se refere às políticas penitenciárias estaduais, Ferreira e Abreu observam que o período da ditadura militar nelas repercutiu diretamente, em primeiro lugar pela acentuada centralização dos processos decisórios:

A guerra contra o inimigo interno, deflagrada pelo governo militar significou uma intensificação das atividades policiais, que correspondeu a uma canalização de recursos para o reaparel hamento e modernização da Polícia Militar, visando não apenas à repressão às organizações políticas de oposição, mas também ao combate da criminalidade. Data dessa época uma articulação, cada vez mais transparente e sempre crescente, entre 0 funcionamento do aparelho policial e do aparelho penitenciário. ${ }^{2}$

Transparece na crescente articulação detectada uma intensificação das características repressivas das instituições prisionais. No contexto da transição para a democracia, marcada pelo debate acerca da cidadania no Brasil, o governo Montoro (Estado de São Paulo: 1983 - 1987) procurou contrapor a tal quadro a Política deH umanização dos Presídios implantada pela Secretaria de Justiça (então responsável pelos presídios) , 3 tendo à frente 0 advogado José Carlos Dias.

0 caráter moderado das propostas implementadas nessa gestão indica que nunca se chegou a questionar as funções de violência e punição, próprias do sistema penitenciário, mas apenas procurou-seexecutálas através de métodos mais especializadose, portanto, menos violentos. 0 que se percebe é que essas alterações não fogem ao velho Modelo 
Panóptico proposto pelo inglês Jeremy Bentham (século XVIII), baseado na total transparência evisibilidade do cárcereedoscorpos, mas avesso à brutalidade física.

Tal moderação era decorrente da ausência de coesão política do governo estadual em torno da questão penitenciária, mas acabou por dificultar o envolvimento efetivo das entidades de defesa dos direitos humanos, muito atuantes na época, em favor dessa política carcerária. Contraditoriamente, no entanto, as medidas propostas pela humanização foram suficientes para desencadear uma série de reações de certos segmentos sociais, tais como os agentes penitenciários, os juízes, e alguns órgãos da grande imprensa.

0 resultado final dessa intensa disputa de poder em torno das instituições penitenciárias concretizou-se com a proximidade do período eleitoral ${ }_{1}^{4}$ quando ganharam espaço no interior do partido do governo estadual, o PM DB, aqueles que adotavam posições mais duras no tratamento da questão da segurança como um todo. 0 chamado pacote da segurança, lançado pelo então vice-governador e candidato à sucessão estadual Orestes Quércia, constituiu-se como marco da vitória desses setores mais reacionários do partido, ao provocar a demissão do secretário Dias, em junho de 1986.

Além de revelar os estreitos limites das transformações políticas e sociais que estavam em curso naquela conjuntura política, conhecida como transição democrática, tal embate apontou também para as significativas barreiras defensivas que costumam impedir a introdução de qualquer alteração no cotidiano carcerário. A partir da saída do secretário Dias, as prisões paulistas voltaram a ser tradicionalmentegerenciadas, ou seja, cotidianamente administradas através de um conjunto de práticas e procedimentos que transitam entre o formal e o informal, com grande autonomia e sem nenhuma transparência, quer para outros órgãos do Estado, quer para a sociedade civil.

Para o pesquisador atento ficava, entre outras lições, aquela relativa à importância deselevar em conta uma pluralidadedesujeitos, quando se trata da questão carcerária, tanto diretamente envolvidos com o cotidiano da prisão - como os agentes penitenciários - como indiretamente - como os juízes e a mídia. 
ANOS 1990: UMA NOVA POLÍTICA PENITENCIÁRIA NO ESTADO DE SÃO PAULO?

A partir de 1997, a mídia foi um dos espaços de divulgação dos planos do governo Covas ( 1992 - 2001)5 para a área carcerária, com destaque para a inusitada construção simultânea de 21 novas penitenciárias, a maioria das quais situadas no interior do Estado de São Paulo.

Mas a mídia também se tornou palco de denúncias, debates, e principalmente de notícias sensacionalistas acerca do sistema penitenciário, sempre envolvendo a violência. Para melhor compreender tal papel desempenhado pela mídia é necessário considerar que uma das peculiaridades do vasto repertório de violências contemporâneas é a visibilidade.

N esse sentido, o tratamento conferido ao tema da violência garante que nos reportemosfreqüentemente mais a uma violência representada que a uma violência real. 0 que não significa que não haja uma relação entre o real e o representado, embora as relações entre ambos sejam variáveis, de acordo com o grau de sensacionalismo empregado, por exemplo. É a partir desse referencial ${ }^{6}$ que podemos compreender o papel desempenhado pela mídia na construção de representações acerca das instituições penitenciárias e sua influência, sobretudo em regiões como - OestePaulista, em que central izamos nossa análise, com a questão tendo adquirido uma dimensão inusitada a partir de 1997.

"Há uma revolução em curso no sistema penitenciário paulista", com esta frase bombástica o então secretário deAdministração Penitenciária, João Benedito de Azevedo Marques, anunciou os planos, já em andamento, do governo Covas para a área penitenciária. Seguiu explicando que "sua face mais visível é a construção simultânea de 21 novas penitenciárias e três presídios semi-abertos, no maior projeto de ampliação de vagas em 50 anos". ${ }^{\prime}$

Embora se apressasse em estabelecer que tal revolução não se resumia a "levantar paredes egrades", o experiente secretário não se referiu à atuação do governo estadual na área como nova política penitenciária. A hipótese desse trabalho era que se tratava de um esforço no sentido de diferenciar-seda última experiência paulista deintervenção no setor, efetivada durante o governo de Franco Montoro, quando Azevedo Mar- 
ques também teve atuação expressiva como coordenador da COESP (Coordenadoria Estadual de Assuntos Penitenciários).

A Política de Humanização promovida pelo governo Montoro (1983-1987) não previa, no entanto, a construção de novas unidades penitenciárias, resumindo-se, nesse âmbito, a reformas, conclusões de obras e a uma polêmica proposta de duplicação de vagas em penitenciárias, então caracterizadas por celas individuais. É provável que isso se devesse sobretudo à crise econômica engendrada durante o regime militar, cujas conseqüências foram fortemente sentidas pelos primeiros governos estaduais eleitos na década de 1980.

Em 1997, rompendo o abandono longamente perpetuado da área carcerária, o governo federal (sob a presidência de Fernando Henrique Cardoso, do PSDB, mesmo partido do governador do Estado de São Paulo) anunciou a liberação de verbas destinadas à construção de novas penitenciárias na intenção de sanar o déficit herdado. No Estado de São Paulo, o Estado brasileiro portador da maior população carcerária do País e da maior carência de estabelecimentos penais, segundo dados do Censo Penitenciário de 1997, o déficit era de 11.652 vagas.

Com a verba liberada pel o governo federal, o governo paulista lançou um megaprojeto que objetivava prioritariamente a desativação da Casa de D etenção deSão Paulo ${ }^{9}$ eà diminuição da superlotação dos Distritos Policiais paulistanos. Foram construídas 21 novas unidades prisionais fechadas e 3 semi-abertas, todas no interior do Estado, 13 delas no Oeste Paulista.

Ante a crise econômica que já assolava o Brasil, materializada particularmente no desemprego, tornavam-se ainda mais limitadas as possibilidades da volta ao mercado de trabalho pelos presidiários. As pequenas emédias cidades do interior paulista vivenciavam cotidianamente o fechamento de empresas, que não sobreviviam à crise. Foi nesse contexto que as 18 mil vagas de trabalho estimadas para as novas unidades prisionais, a partir de investimentos de R\$230 milhões, ganharam dimensão específica.

Dois discursos convergentes envolveram essas instituições, especialmente no período eleitoral em que foram inauguradas. Por um lado, o alívio prometido à população da capital paulista em função da descentralização da população carcerária em direção às penitenciárias 
do interior do Estado; por outro lado, a promessa de centenas de novos empregos para as regiões interioranas, destacadamente afetadas pela crise econômica.

Prefeituras ofereceram cursos preparatórios aos muitos candidatos locais para o preenchimento das vagas, mediante concurso público. M as houve também casos em que a prorrogação de prazos de inscrição foi ocasionada pela falta de candidatos. Dentre aqueles que chegaram a seinscrever nos concursos, observava-se um desconhecimento generalizado das implicações dessa opção, ou seja, do que significa trabalhar num presídio. Aqueles que tinham amigos ou parentes trabalhando no sistema penitenciário eram as exceções.

Ao longo do tempo, os novos funcionários foram sofrendo o efeito de contágio quea prisão exerce não apenas sobre ospresos, mas também sobre os agentes que estão em contato constante com eles. Trata-se da chamada prisionalização, já abordada por especialistas com alcances diversos, ${ }^{10}$ percebida de forma bastante concreta no cheiro de cadeia que impregna presos e agentes, e na linguagem carcerária - a famosa gíria de cadeia - criada pelos presos, para não ser entendida pelos agentes, mas que acaba por ser incorporada por muitos deles, chegando inclusive às ruas. Por último, um dos indícios mais significativos desse processo éa tendência partilhada de ocultar tudo o que ocorre na prisão. Como observa M olina, pesquisando prisões espanholas, pareceaos envolvidosque "quanto menos se fala da prisão, melhor". ${ }^{11}$

Assim, constata-se uma regra comumenterespeitada dentro do sistema penitenciário, a lei do silêncio. Ela éincorporada pel os novos agentes deforma muito rápida. A compreensão de que o seu papel de contato cotidiano e direto, único e exclusivo, entre o interior e o exterior das mural has não é apenas desgastante e perigoso, mas pode tornar-se instrumento de poder, passando a ser então explorada. Quanto menos se sabe mais fácil será a dominação, como bem mostrou M ichel Foucault. ${ }^{12}$

A multiplicidade de significados das altas mural has é um aspecto a ser levado em conta. Tão importante quanto a segurança, supostamente garantida pela contenção, é a ausência de transparência. 0 olhar, ainda que parcial, do interior para o exterior é garantido pelas telas das TVs. M as o contrário não é verdadeiro. Do interior para o exterior, o olhar só penetra em situações excepcionais, parcialmente durante as preparadas 
visitas, e em momentos de ruptura radical da ordem, durante motins e tentativas de fuga noticiadas pela mídia. Nestas raras ocasiões, as atenções da sociedade voltam-se para a questão penitenciária que, representada como ameaça iminente, passa a preocupar a todos. De modo ambíguo, a mídia reflete e influencia a discussão então desencadeada. Mas isto sempre dura pouco, e então o véu que costuma encobrir a questão penitenciária é recolocado.

Outro aspecto importante dessa lei do silêncio é o monopólio e a supervalorização de um suposto saber prático sobre o cotidiano carcerário, de que nos fala Goifman, ${ }^{13}$ que pode ser identificado na frase freqüente entre os agentes: "Vocênão está no raio, ${ }^{14}$ não sabe o queacontece, falar é fácil, mas somente quem está no raio sabe como é." Autorepresentando-se como um misto de vítimas e de heróis, utilizam esse argumento para justificar práticas dificilmente aceitáveis, ou simplesmente para encobri-las.

Reforçando a permanência que caracteriza o aspecto ora discutido, lembramos as observações do médico Drauzio Varella sobre a Casa de Detenção de São Paulo:

Os jornalistas, por sua vez, são os mestres no desagrado, conseguem inimizades entre gregos e troianos. De medo que alguma vítima antiga lhes reconheça a fisionomia e novos processos aumentem o débito com a Justiça, os presos fogem das objetivas como o diabo da cruz. Apontar-Ihes uma máquina fotográfica ou câmara de TV faz com que cubram o rosto e desapareçam mais depressa do que de uma metralhadora da PM. Os funcionários também evitam a imprensa, dizem que ela só serve para criticar e distorcer tudo que é dito. ${ }^{15}$

Nota-se neste caso uma certa conivência. A ausência de transparência pode atender a interesses diversos, muitas vezes antagônicos, de agentes e presos. Todavia, a reivindicação da presença das câmaras de TV durante motins, por exemplo, além de representantes do Poder Judiciário, cada vez mais freqüentes, sugere a incorporação dessas novas tecnologias do olhar pelos presos, ao menos em certas situações. Ademais, o papel desempenhado pela câmara de vídeo na pesquisa recente realizada por Goifman ${ }^{16}$ em penitenciárias e distritos policiais brasileiros aponta no mesmo sentido. 
M as as observações de Varella ${ }^{17}$ desvendam também uma outra característica das penitenciárias, velhasenovas. Trata-seda sua incapacidade de aceitar críticas, às quais reagem semprecom maior fechamento, como também observou M olina ${ }^{18}$ nas penitenciárias espanholas, atestando mais uma vez o caráter intrinsecamente autoritário dessa instituição.

Dentre as características comuns às novas penitenciárias, que sugerem o não-rompimento do padrão encontrado nas antigas instituições prisionais, emergem posturasmarcadamentecompetitivas dos agentes em relação aos presos. Ao contrário de muitas outras questões, que só podem ser compreendidas atentando-se para as especificidades do microcosmo prisional, a questão da cidadania na sociedade brasileira éa chave para o entendimento de tão marcada competitividade. Partimos das observações de Paoli que, discutindo a violência brasileira, percebeu que muitos dos estudos sobre ela acabaram convergindo para o tema da cidadania, mas em geral não levaram em conta a heterogeneidade da sociedade civil em questão, limitando-se

[...] a refletir sobretudo a experiência daqueles que- seja em função de sua classe social, seja em função de interesses sociais, profissionais e políticosjá conhecem o conteúdo substantivo da cidadania como discurso e se sentem em condições de reivindicar sua promessa, isto é, o direito ao poder. ${ }^{19}$

Constatamos que são pessoas que não têm a noção de cidadania que vêem como regalia o reconhecimento de direitos básicos dos presos, pobres como eles, porém pertencentes ao mundo do crime. Numa pesquisa desenvolvida em 1999 pelo Núcleo de Estudos da Violência (NEV - da Universidade de São Paulo - USP), na periferia da Grande São Paulo, Adorno e Cardia ${ }^{20}$ observaram que o medo da violência, longe de unir a sua população, tende a opor uns aos outros. Aqueles que estão mais abaixo na estrutura social passam a ser vistos como os mais ameaçadores. 0 que dizer então dos presos, quealém de serem pobres, em sua imensa maioria, ainda cometeram crimes ? N um contexto em que "para eu ter direito, alguém não vai ter, porque não dá para todos", ${ }^{21}$ isto é, de "escassez de direitos", a exclusão se potencializa quando impede uma perspectiva mais ampla da sociedadeque por direito teria que seampliar, incorporando os cidadãos. Resta então um processo de auto-afirmação centrado na reprodução da exclusão. 
Como age instituição penitenciária perante a essas disputas entre presos eagentes, que estão na base do seu cotidiano?Ao quetudo indica, ela reforça tais relações, ampliando seu controle sobre cada um dos segmentos envolvidos, ao apostar na potencialização da oposição historicamente construída com esse objetivo. Como mostrou Foucault, ${ }^{22}$ trata-se de desenvolver, dentro dos muros, estratégias de controlea serem aplicadas fora deles.

Além dos agentes, outros profissionais também participam do ambiente prisional, embora de maneira muito menos constante e intensa. Alguns deles compõem a Equipe Técnica, que tinha como principal função a elaboração dos Exames Criminológicos exigidos para a concessão dos benefícios aos presos. ${ }^{23} \mathrm{~N}$ ão obstante as boas intenções de muitos deles, na prática a concessão dos benefícios tornou-se prioritária e burocrática por significar a rotatividade entre os presos, ou melhor, a disponibilização constante de novas vagas.

Há indícios de que esse poder, exercido com exclusividade pela Equipe Técnica, não era bem-visto pelos agentes, que reclamavam pelo não-reconhecimento do seu saber construído através da observação cotidiana dos presos. A despeito das melhores condições materiais oferecidas pelas novas penitenciárias, o conflito interno - entre os diretamente encarregados da segurança e os supostamenteencarregados da reabilitação - identificado nas antigas e superlotadas instituições se mantém, opondo profissionais sem qualificação, com longasjornadas de trabalho e remuneração inferior, a profissionais especializados que trabalham menos e são melhor remunerados.

$M$ as além dessas permanências, também identificamos mudanças na atuação dos profissionais especializados. A partir da década de 1990, alguns deles têm transformado suas experiências no sistema penitenciário em trabalhos de pesquisa em forma de dissertações e teses. Psicólogos, assistentes sociais e professores têm revelado assim a capacidade de manter um ponto de vista crítico, superando as dificuldades mencionadas relacionadas à prisionalização, e apontando para a possibilidade de rompimento da lei do silêncio que costuma envolver as penitenciárias. Desta maneira, vão ao encontro da proposta de M olina para o enfrentamento da questão penitenciária: [...] “énecessária a presença ativa de outras pessoas, não prisionalizadas e que tragam outros 
projetos, que não pertençam ao estrito, limitador e sufocante mundo da prisão, que rompam essa tendência de toda instituição total de fechar-se sobre si mesma."24

Mas, apesar do caráter promissor desses trabalhos, permanece a contradição entre a rotina burocratizada de profissionais, como psicólogos e assistentes sociais, que deveriam desempenhar papel-chave na recuperação dos presos, e a crítica produzida por uma minoria, tanto sobre a instituição quanto sobre seu próprio desempenho profissional.

Dentre esses profissionais especializados destacam-se, pela singularidade de sua posição no universo prisional, as professoras. Papel em geral desempenhado por mulheres, pouco valorizado, o que é atestado inclusive pela baixa exigência de seus concursos, baixa remuneração e pela sua designação como "monitoras", em vez de professoras, garante o funcionamento de salas de aula normais, a saber, muito semelhantes às de qualquer escola. Quadro-negro, carteiras, material escolar básico, com a presença da professora e de vinte a trinta alunos atestam tal normalidade. A grade nas janelas, a porta trancada e a figura de um agente do lado de fora, assim como o controle exercido pelo diretor de Educação sobreo acesso ao material escolar fornecido por uma fundação (FU NAP - Fundação Professor Dr. M anoel Pedro Pimentel, da própria Secretaria deAdministração Penitenciária do Estado de São Paulo), denunciam sua excepcionalidade.

Segundo depoimentos colhidos junto aos alunos-presos, além da oportunidade de aprender, a escola possi bilita o rompimento cotidiano, ainda que por duas horas apenas, da rígida disciplina carcerária e da massificação a ela inerente. As professoras esforçam-se por garantir possibilidades de expressão individual, que incluem críticas à instituição, ao Estado, à sociedade, e a autocrítica, além de oportunidades cuja importância só pode ser percebida por homens presos, como usar individualmente o banheiro. Tudo no maior respeito, no qual se baseia inclusive a autoridade de mulheres que se dispõem a ficar sozinhas com esses alunos especiais, já que costuma partir delas a exigência de que o agente encarregado dezelar pela segurança da escola permaneça do lado de fora da sala de aula. M uitos presos chegam a dizer que quando vão à escola ou quando dormem não se sentem encarcerados, demonstrando que a liberdade pode ter múltiplos significados. 
Dentre as dificuldades relatadas pelas professoras, destaca-se a alta rotatividade dos alunos (decorrentes das transferências e benefícios), a dificuldade de acesso às aulas pelos alunos-presos, imposta por agentes penitenciários, além da dificuldade de acesso ao material didático, imposta pelo diretor de Educação. A partir desses relatos, podemos compreender a origem de tais problemas de duas maneiras: são decorrentes da forte prevalência da segurança sobre qualquer outra função no presídio e das já referidas disputas internas de poder.

Ambas implicam uma representação negativa dos agentes sobre a escola. Do ponto de vista dos presos, a escola é o espaço onde eles têm um pouco deliberdade, em função da rara oportunidade de se expressarem, de conversar com outras pessoas, aprender e principalmente de reativar a sua individualidade. $A$ despeito disso ou, quem sabe, também por isso, da perspectiva dos agentes, a escola é um empecilho a atrapaIhar a rotina do presídio, que obriga a liberar os presos nos horários estabelecidos em função das aulas, além de fazer revista antes de entrarem eapós saírem da sala de aula.

Alguns agentes declaram abertamente que não deveria haver escola nos presídios, sugerindo que o ensino seja visto como uma regalia e não como um direito, numa inversão típica da prisão, na qual até mesmo 0 trabalho - externamente visto como obrigação - pode tornar-se regalia, sobretudo quando se trata de proibir o acesso do preso à oficina, por exemplo, como forma de punição.

Com o objetivo de tentar compreender como esse cotidiano penitenciário se constitui nos anos 1990, entre mudanças e permanências, em sua relação com a história das penitenciárias brasileiras das últimas décadas ea história social epolítica do Brasil no mesmo período, procuramos dar voz aos outros personagens dessa história, além dos presos. M as pelosimpedimentos mencionados anteriormente, além das dificuldades impostas pelas autoridades responsáveis, isso só tem sido possível através do esforço de valorização de indícios, aparentemente negligenciáveis. Tal como propõe Carlo Ginzburg, "se a realidade é opaca, existem zonas privilegiadas - sinais, indícios - que permitem decifrá-la". 25

Desse modo é que mesmo práticas já institucionalizadas, como as aulas, ${ }^{26}$ continuam a ser desconhecidas da população, constituindo-se em zonas "opacas", porém valorizadas pelo pesquisador. Mas por que 
esse desconhecimento geral? A hipótese deste trabal ho é que isto se relaciona não apenas com as especificidades da instituição penitenciária, mas também com a atual conjuntura política e social do Brasil.

ANOS 1990: A POLÊMICA EM TORNO DA NOVA TERRITORIALIZAÇÃO DOS PRESÍDIOS PAULISTAS

Do ponto devista político, uma das herançasfundamentais dosanos 1980 foi a promulgação de uma nova Constituição, em 1988, festejada por políticos tradicionais que fizeram oposição ao regime militar, como Ulisses Guimarães, do PSDB, como “Constituição cidadã”; interpretada pelo economista Francisco de Oliveira como "a mais acabada que as condições históricas permitiam", ${ }^{27}$ e pelo historiador Boris Fausto como 0 reflexo dos avanços ocorridos no País, "especialmente na área da extensão de direitos sociais e políticos aos cidadãos em geral e às minorias". ${ }^{28}$

M as se a questão política parecia ter se estabilizado no domínio da democracia liberal, do ponto de vista econômico os índices de desemprego, a despeito da frieza dos números, são eloqüentes: conforme dados do M inistério do Trabalho, de julho de 1994 até o início de 1997 foram eliminados 755 mil empregos formais no Brasil; no período de 1990-1996 a cifra chega a 2,4 milhões.

Um dos aspectos a serem analisados para a compreensão desse quadro, além da referida mundialização do capital, foi a política de privatizações adotada pelo governo de Fernando Henrique Cardoso (PSDB) em seu dois mandatos ( 1995 - 2002). Ao apontar para mudanças nas relações entre público e privado no Brasil, essa política ultrapassou o âmbito econômico.

De acordo com Oliveira, "a privatização do público é uma falsa consciência da desnecessidade do público". ${ }^{29}$ D esse ponto de vista, ocorreuma inversão do processo que construiu o Estado do Bem-Estar Social, quando houve uma privatização do público e, em contrapartida, o publicismo do privado. A partir dos anos 1990 difundiu-se a ideologia das elites, segundo a qual o Estado está falido em função da dívida pública interna que, por sua vez, só se sustenta graças às contribuições da própria elite, ou seja, como extensão do privado. 
M as Oliveira esclarece que o processo real é o inverso: "a riqueza pública, em forma de fundo, sustenta a reprodutibilidade do valor da riqueza, do capital privado. Essa é a forma moderna de sustentação da crise do capital".30

Ainda segundo esse autor, há um outro aspecto trágico da privatização do público em curso no Brasil, diretamente relacionado à atuação da instituição de controle social mais visível dessa sociedade - a polícia. Muito se tem falado, desde o fim da ditadura, sobre a propalada impotência do Estado de deter a onda de violência que parece atingir a sociedade brasileira. Tal impotência tem sido associada fundamentalmente à sua incapacidade de monopolizar a violência legal, por seu turno atribuída à sua dilapidação financeira.

A esse quadro se acrescenta um suposto desinteresse das el ites pela polícia, em seu sentido literal, como instrumento público demonopólio da violência. Ainda que associado ao desinteresse mais geral pela coisa pública, Oliveira atribui ao mesmo um caráter de falsidade, na medida em que implicou um isolamento material dessas elites em condomínios fechados, cercados por seguranças privados. Reconhecem, desse modo, "um estado de guerra civil larvar e, em alguns casos, aberta", ${ }^{11}$ que por sua vez também decorre de tal omissão.

Levando-se ainda em conta as constatações de Caldeira ${ }^{32}$ acerca do início dos anos 1990, quando detecta que a crença no progresso deu lugar ao pessimismo eà frustração, a sentimentos expressos e organizados nas falas sobre o crime por ela colhidas, confirma-se a hipótese deste trabalho acerca das relações entre o interior e o exterior das penitenciárias, vale dizer, entre mudanças e permanências sociais, políticas, econômicas e mesmo culturais, e a maneira como se representa, e conseqüentemente, se trata o diferente, seja ele o criminoso, o louco, o homossexual ou 0 aidético.

No entender de Caldeira, ${ }^{33}$ não é casual, portanto, a coincidência temporal entre democratização política e privatização dos espaços públicos, pelo contrário, esses processos estariam intimamente relacionados. Como ele interpreta, tal privatização seria um modo de reagir das elites à ampliação do processo de democratização, uma vez que funciona para estigmatizar e excluir aqueles que acabaram de forçar seu reconhecimento como cidadãos. 
Por último, ainda que os autores citados não o façam, consideramos fundamental acrescentar mais um elemento a esse quadro - as novas características assumidas pelo desemprego no Brasil, nas últimas décadas. Trata-se da ausência de perspectivas de retorno ao mercado de trabalho formal, o que, por sua vez, significa ser socialmente representado como descartável, perigoso, emesmo desumanizado. Daí a relevância adquirida atualmente pelo conceito de exclusão social que, embora não se trate de um fenômeno novo, tem o mérito de apontar também para sua dimensão cultural, ajudando a desvendar a dramaticidade da situação vivida pelos tais excluídos em países como o Brasil e, por conseqüência, para o redimensionamento da importância das instituições de controle social.

Nesse contexto, cuja complexidade apenas começa a ser vislumbrada, é que deve ser compreendida a polêmica desencadeada pela nova territorialização dos presídios paulistas, em particular no O estePaulista, ondemais de vinte penitenciárias estão concentradas desde os anos 1990.

Como já foi mencionado, dois discursos convergentes envolveram essas instituições, mormente no período eleitoral (eleições para o governo estadual ocorridas em 1996) em que foram inauguradas - o alívio prometido à população da capital paulista graças à descentralização da população carcerária levada às penitenciárias do interior do Estado e a promessa de centenas de novos empregos para as regiões interioranas, particularmente afetadas pela crise econômica.

Considerando-se os dados divulgados pela mídia acerca do crescimento do número de condenados, sugerindo a ineficiência de uma política penitenciária baseada na expansão de vagas e a mensagem implícita nos discursos citados de que o perigo estaria sendo deslocado para 0 interior, e ainda numa visão individualista crescente nessa conjuntura política típica de uma sociedade cindida - de que as grandes cidades produzem os criminosos, mas as pequenas e médias é que teriam que conviver com eles - é que a polêmica foi sendo alimentada pela mídia e por políticos da região, interessados em explorá-la a seu favor.

Assim, retornamos à pergunta anteriormente formulada: Por que nada, ou quase nada se divulga acerca do cotidiano dos presídios, e em particular acerca das práticas voltadas à ressocialização implementada no interior das muralhas? 
A hipótese deste trabalho éde queprevalecem interesses eleitoreiros também no âmbito do governo do Estado, principal responsável pela política penitenciária. Isto significa que a temporalidade rápida e imediatista das campanhas eleitorais évista como inconciliável com as mudanças lentas, além de limitadas, das instituições prisionais. Outrossim, num contexto político em quea defesa dos direitos humanos tornou-se sinônimo de defesa dos direitos dos bandidos, numa deturpação obtida em virtude da intervenção cotidiana de responsáveis por programas policiais sensacionalistas, de rádio e de TV, mas também de autoridades da área da Segurança Pública freqüentemente identificadas com a instituição policial, a divulgação de investimentos feitos na edu cação dos detentos poderia não ser bem vista pela população, sobretudo num contexto de "escassez de direitos" 34 que atinge até mesmo os trabalhadores. Ocorre então a reprodução de representações sociais acerca dos presídios limitadas à contradição entre controle, como sinônimo de segurança, por um lado, e o perigo, associado ao desconhecimento acerca do que realmente acontece atrás das mural has, com um tratamento sensacionalista dado à questão penitenciária pela mídia, em geral, que em quase nada se diferencia da função de "vigiar e punir" identificada por Foucault. ${ }^{35}$

Um exemplo do papel emblemático desempenhado pela mídia na construção dessas representações da violência, e que tem influenciado diretamente o Oeste Paulista, diz respeito ao noticiário publicado a partir de 19 de fevereiro de 2001 sobre a ocorrência simultânea de motins em mais de 20 penitenciárias e casas de deten ção da capital e do interior paulista. A partir daí muito sefalou acerca do PCC (Primeiro Comando da Capital), uma organização de presos espalhada por diversas unidades prisionais, e sobre motins carcerários ocorridos, possíveis ou supostamente planejados. No caso dos jornais interioranos, a discussão foi direcionada para as reações contra a possi bilidade de que novas penitenciárias viessem a ser construídas nas respectivas cidades.

Desse modo, maisuma vez um acontecimento excepcional, quesignificou a quebra radical da rotina carcerária, fez com que um assunto pouco abordado pela mídia merecesseatenção, dessa vez ao longo demeses. M as como pouco ou quase nada se fala dos presídios no seu dia-a-dia, sobreo seu cotidiano de isolamento, quando se enfatizam esses acontecimentos extraordinários que são os motins de presos, explorando-os atéa 
exaustão deforma sensacionalista, produz-seuma imagem invertida dessas penitenciárias, que passam a ser representadas como locais onde não há rotina por obra das manifestações violentas e ameaçadoras dos presos. 0 que é excepcional assume, assim, a aparência de regra.

Em 2000, durante o ano todo ocorreram 25 motins no Estado de São Paulo, segundo dados da Secretaria deAdministração Penitenciária. Como 74 unidades penitenciárias estavam funcionando no Estado, concluímos que a maioria delas não registrou nenhum motim. Isto sem levar em conta que a maior parte dos motins acaba sem qualquer fuga de presos, e em geral com eventuais mortos e freqüentes feridos entre os próprios presos.

Numa sociedade em que o diferente é rejeitado, culpabilizado pelos problemas sociais e identificado com certos lugares como cortiços e favelas, a representação do preso como desumano, perigoso e irrecuperável se radicaliza a partir dessas coberturas da mídia, como se o crimee, portanto, o criminoso não fizesse, intrínseca e contraditoriamente, parte dessa sociedade.

Cerca de vinte anos depois de encerradas as lutas da sociedade civil pelo fim da ditadura, quando a própria memória dessas lutas torna-se objeto de interesse exclusivo dos historiadores, os anos 1990 caracterizaram-se, na H istória do Brasil, principalmente pela consolidação da democracia liberal, pela crise econômica relacionada à mundialização da economia, ${ }^{36}$ ao desemprego estrutural e à nova exclusão social, pel o aumento da violência urbana e, mais ainda, pelo medo que passou a demarcar o cotidiano de quem vive nas cidades brasileiras. Cal deira observa que, como resultado dessa combinação, "para muitas pessoas o dia-a-dia na cidade está se transformando numa negociação constante de barreiras e suspeitas, e é marcado por uma sucessão de pequenos rituais de identificação e humilhação". ${ }^{37}$ Diante de tal quadro, como são representados os presídios com seu cotidiano demarcado por barreiras, suspeitas e humilhações, para além do isolamento?

A banalização desses procedimentos e a percepção de que "para eu ter direito, alguém não vai ter, porque não dá para todos", ou seja, de que há "escassez de direitos", 38 sugerem que a resposta a essa questão, ainda que remeta ao já abordados neste trabal ho, e mesmo a outros indícios de desrespeito grave a direitos humanos dentro dos presídios, como a exis- 
tência de celas de castigo (potes, segundo a gíria da cadeia) insalubres e caracterizadas como "sobrepenas", punições violentas, que podem chegar a causar a morteem razão de envolvimento em motins, por exemplo, etc., não sinalizam apenas brechas ou fissuras na democracia ou na própria sociedade brasileira, mas desvendam seus limites, contradições, enfim, problemas intrínsecos, ainda que, ou por isto mesmo, problemas renegados. Neste sentido, as altas muralhas penitenciárias representariam também um esforço da sociedade de isolar por completo parte de si mesma.

GÓES, Eda Maria. Political transition and the quotidian of São Paulo's penitentiary. História, v. 23 (1-2), p. 219-238, 2004.

A BSTRACT: This paper dedicate oneself to the study of the 1980's and 1990's decades in Brazil, since political transition, searching also to approach its extend that materialized, the most part, at the 1990's. The approach is based on establishing relations among political changes, its possibilities and its limits, and the quotidian of São Paulo's prisons institutions initially, and afterwards of a specific region: the São Paulo western. We could reach, then, to identify distinct own temporalities of each one, sometimes materialized in fissures at democratization process that involved human rights discussion, besides the identification of common and specific power relationship.

KEYW O RD S: São Paulo State prisons; M ilitary period; quotidian history.

\section{NOTAS}

${ }^{1}$ Departamento de Geografia - Faculdade de Ciências e Tecnologia - UNESP - CEP 19.060-900 - Presidente Prudente - São Paulo - Brasil. edagoes@prudente.unesp.br ${ }^{2}$ FERREIRA, R. M . F. eABREU, S. A. F. Análise do Sistema Penitenciário do Estado de São Paulo: 0 gerenciamento da marginalidade social. São Paulo: CEDEC, fev. 1987. p.70. (Relatório de Pesquisa).

${ }^{3}$ A Secretaria de Administração Penitenciária foi criada no Estado de São Paulo pelo governador Luís Antônio Fleury Filho, depois do massacre do Carandiru, ocorrido em outubro de 1992, quando 111 presos (números oficiais) foram mortos pela Polícia M ilitar durante a repressão a um motim na Casa de Detenção de São Paulo. 
${ }^{4}$ Esse período eleitoral precede as eleições estaduais de novembro de 1986, nas quais Orestes Q uércia, do PM DB, foi eleito governador do Estado de São Paulo.

${ }^{5}$ Em 2001, o governador Mário Covas faleceu, durante o seu segundo mandato, e foi substituído pelo vice-governador Geraldo Alckmin, do mesmo partido político, o PSDB, que por sua vez foi eleito governador no final do mesmo ano, tomando posse em 2002.

${ }^{6}$ IM BERT G. Los escenarios de la violencia. Barcelona: Icaria,1992.

${ }^{7}$ O Estado de S. Paulo, 28.7.1998.

${ }^{8}$ Idem.

${ }^{9}$ Desativada em 2002, a Casa de Detenção de São Paulo era considerada um verdadeiro barril de pólvora, em função da superlotação crônica e do histórico de motins violentos, entre os quais destaca-se aquele que ficou conhecido como massacre da Detenção (outubro de 1992). Sua localização num bairro populoso da capital paulista tornava a sua situação ainda mais preocupante.

${ }^{10}$ Como exemplo, ver: Molina, J. V. La carcel y sus consecuencias: la intervención sobre la conducta desadaptada. Espanha: Editorial Popular, 1997, p.152.

11 Idem, p.151.

${ }^{12}$ FOU CAU LT, M. M icrofísica do Poder. 11.ed., Rio de Janeiro: Graal, 1993.

${ }^{13} \mathrm{GOIFM} A N, K$. Valetes em slow motion - a morte do tempo na prisão: imagens e texto. Campinas: Ed. UNICAM P, 1998.

${ }^{14}$ Denominação de cada um dos corredores de acesso às celas, que compõem a estrutura física das penitenciárias.

${ }^{15}$ VARELLA, D. Estação Carandiru. São Paulo: Cia. das Letras, 1999, p.106.

${ }^{16}$ GOIFM AN, K. Op. cit.

${ }^{17}$ VARELLA, D. Op. cit.

${ }^{18}$ M OLINA, J. V. Op. cit.

${ }^{19}$ PAOLI, M. C. Conflitos sociais e ordem institucional: cidadania e espaço público no Brasil do século XX. Revista da OAB. São Paulo: Brasiliense, n. 53, p. 50, 1989.

${ }^{20}$ ADORNO, S. e CARDIA, N. Dilemas do controle democrático da violência: execuções sumárias e grupos de extermínio. In: SANTOS, J. V. T. dos. (org.) Violência em tempo de globalização. São Paulo: Hucitec, 1999, p.74.

${ }^{21}$ CARDIA, N. Raízes da violência. Problemas brasileiros. São Paulo, n. 333, maio/ junho 1999, p.9.

${ }^{22}$ FOUCAULT, M. Op. cit.

${ }^{23} \mathrm{~A}$ partir de decreto promulgado em 2004, as Equipes Técnicas foram extintas e a decisão acerca da concessão de benefícios aos presos passou a ser tomada exclusiva- 
mente pelo juiz. Desde então, o papel a ser desempenhado por assistentes sociais nos presídios está indefinido.

${ }^{24}$ M OLINA, J. V. Op. cit., p.152.

${ }^{25}$ GINZBU RG, C. M itos, emblemas e sinais. São Paulo: Cia das Letras, 1989, p.177.

${ }^{26}$ Outros projetos, voltados ao estímulo do processo de conquista da cidadania pelos presos, foram desenvolvidos em presídios paulistas durante os anos 1990: projeto "Bem viver - saúde e saber" e projeto de teatro nas prisões "Direitos Humanos em cena," por exemplo.

${ }^{27}$ OLIVEIRA, F. de e PAOLI, M. C. (org.). Os sentidos da democracia. Políticas do dissenso e hegemonia global. Rio de janeiro: Vozes, 1999, p.65.

${ }^{28}$ FAUSTO, B. H istória do Brasil. São Paulo: Edusp/FDE, 1996, p.525.

${ }^{29}$ OLIVEIRA, F. de. Op. cit., p.68.

30 Idem.

${ }^{31}$ Idem, p. 69.

${ }^{32}$ CALDEI RA, T. P. do R. Cidade de muros. Crime, segregação e cidadania em São Paulo. São Paulo: Ed. 34/Edusp, 2000.

${ }^{33}$ Idem.

${ }^{34}$ CARDIA, N. Op. cit.

${ }^{35}$ FOU CAULT, M. Op. cit.

${ }^{36}$ SANTOS, M. Por uma nova globalização: do pensamento único à consciência universal. Rio de Janeiro: Record, 2000.

${ }^{37}$ CALDEIRA, T. P. do R. O p. cit., p.319.

${ }^{38}$ CARDIA, N. Op. cit., p.9.

Artigo recebido em 08/2004. Aprovado em 11/2004 